\title{
Pancreatitis with electrocardiographic changes mimicking acute myocardial infarction
}

\author{
Paul Khairy MD CM FRCPC, Pierre Marsolais MD FRCPC
}

P Khairy, P Marsolais. Pancreatitis with electrocardiographic changes mimicking acute myocardial infarction. Can J Gastroenterol 2001;15(8):522-526. A 64-year-old woman with mild acute pancreatitis presented with epigastric pain, nausea and vomiting while undergoing hemodialysis for chronic renal insufficiency. Serial electrocardiograms revealed new onset ST segment elevations in leads V2 to V4 mimicking an anterior myocardial infarction, followed by diffusely inverted deep T waves. No cardiac pathology was demonstrated by echocardiography or coronary angiography. A review of the literature and possible pathophysiological mechanisms of electrocardiographic changes in acute pancreatitis, such as metabolic abnormalities, hemodynamic instability, vasopressors, pericarditis, myocarditis, a cardiobiliary reflex, exacerbation of underlying cardiac pathology, coagulopathy and coronary vasospasm, are discussed.

Key Words: Cardiobiliary reflex; Myocardial infarction; Myocarditis; Pancreatitis; Pericarditis

\section{Pancréatite accompagnée de modifications de l'ECG, simulant un infarctus aigu du myocarde}

RÉSUMÉ : Une femme de 64 ans souffrant d'une pancréatite aiguë légère est venue consulter pour des douleurs épigastriques, des nausées et des vomissements pendant qu'elle était suivie en hémodialyse pour de l'insuffisance rénale chronique. Des électrocardiogrammes (ECG) en série ont révélé l'apparition d'un sus-décalage du segment ST dans les dérivations $\mathrm{V} 2$ à $\mathrm{V} 4$, qui simulaient un infarctus antérieur du myocarde, suivie de profondes ondes $\mathrm{T}$ inversées, réparties çà et là. L'échocardiographie et la coronarographie n'ont pas permis de mettre en évidence une cardiopathie. Suit donc une discussion sur l'examen de la documentation ainsi que sur les mécanismes physiopathologiques possibles des modifications de l'ECG, observées dans le contexte de la pancréatite aiguë, comme les troubles du métabolisme, l'instabilité hémodynamique, les vasopresseurs, la péricardite, la myocardite, un réflexe cardio-biliaire, l'exacerbation d'une maladie cardiaque sousjacente, les troubles de la coagulation et les angiospasmes coronariens.
$\mathrm{A}^{\mathrm{l}}$ lthough differentiating acute pancreatitis from an acute coronary syndrome is rarely a source of confusion, subsidiary studies such as serial electrocardiograms (ECGs) may be very helpful when signs and symptoms overlap. A problem arises, however, when pancreatitis presents with ECG changes in the absence of coronary artery disease or hemodynamic instability. Minor transient ECG abnormalities such as nonspecific ST segment depression and $\mathrm{T}$ wave inversions are well described in association with pancreatitis (1-8). Whether pancreatitis presents with major ECG changes such as ST segment elevation in the absence of underlying cardiac pathology remains a subject

Department of Medicine and Intensive Care, Hôpital du Sacré-Coeur de Montréal, Université de Montréal, Montréal, Québec

Correspondence and reprints: Dr Paul Khairy, Montreal Heart Institute, 5000 Bélanger Est, Montreal, Quebec H1T 1C8. Telephone 514-376-3330, fax 514-376-5241, e-mail PaulKhairy@hotmail.com

Received for publication June 9, 2000. Accepted December 6, 2000 


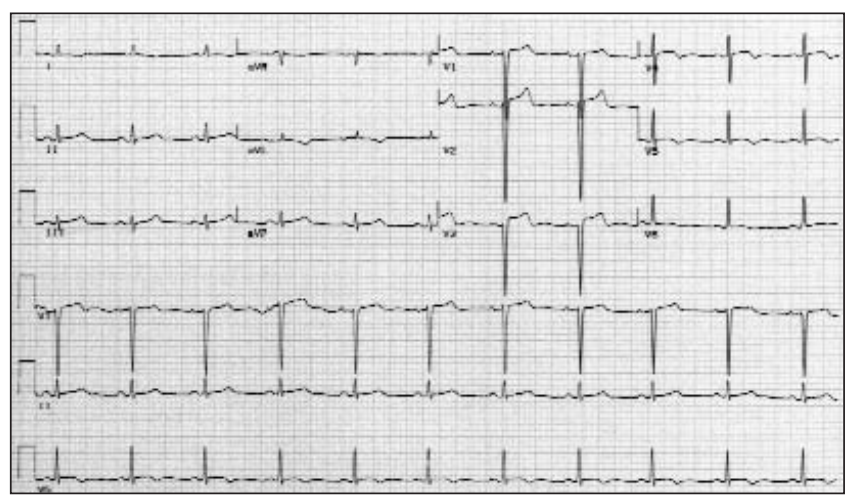

Figure 1) Initial electrocardiogram with 1 to $3 \mathrm{~mm}$ ST segment elevations in precordial leads V2 to V4, and $\mathrm{T}$ wave inversions in the anterolateral leads

of controversy. We describe a patient with acute, mild pancreatitis mimicking an anterior myocardial infarction with a previously normal ECG, as well as normal echocardiographic and angiographic studies.

\section{CASE PRESENTATION}

While undergoing hemodialysis, a 64-year-old white woman with hypertensive end-stage renal failure presented with sudden onset of burning epigastric pain radiating to the chest and back, accompanied by nausea and vomiting. Five hours later, she returned to hospital with nonbloody diarrhea and persisting pain. She denied fever, chills, dyspnea, palpitations, orthopnea, pleuritic chest pain and alcohol consumption. She had no known cardiac disease but had a 45 pack/year smoking history, controlled hypertension and mild dyslipidemia. In addition to chronic renal failure hemodialyzed for two months, her past medical history was remarkable for a peptic ulcer with Helicobacter pylori eradication and a remote cholecystectomy.

Physical examination revealed a hemodynamically stable, nontoxic, afebrile patient, with unremarkable cardiac and pulmonary examinations. Abdominal palpation disclosed epigastric tenderness with no signs of peritonitis. Electrolytes and renal function test results were as follows: sodium $134 \mathrm{mmol} / \mathrm{L}$, potassium $4.7 \mathrm{mmol} / \mathrm{L}$, chloride $100 \mathrm{mmol} / \mathrm{L}$, ionized calcium $1.08 \mathrm{mmol} / \mathrm{L}(4.3 \mathrm{mg} / \mathrm{dL}$, normal 4.4 to $5.3 \mathrm{mg} / \mathrm{dL})$, phosphate $1.87 \mathrm{mmol} / \mathrm{L}(5.79 \mathrm{mg} / \mathrm{dL})$, blood urea nitrogen $14.4 \mathrm{mmol} / \mathrm{L}(40.3 \mathrm{mg} / \mathrm{dL})$ and creatinine $409 \mathrm{mmol} / \mathrm{L}(4.62 \mathrm{mg} / \mathrm{dL})$. High levels of amylase (1364 IU/L), elevated liver enzymes (aspartate aminotransaminase $194 \mathrm{IU} / \mathrm{L}$, alanine aminotransaminase $49 \mathrm{IU} / \mathrm{L}$, lactate dehydrogenase $1384 \mathrm{IU} / \mathrm{L}$, alkaline phosphatase $286 \mathrm{IU} / \mathrm{L}$ ) and a creatine kinase level of $167 \mathrm{IU} / \mathrm{L}$ were noted. Leukocytosis $(17,500 / \mu \mathrm{L})$ with a predominance of neutrophils, normocytic anemia (hemoglobin $98 \mathrm{~g} / \mathrm{dL}$ ) and elevated platelets $\left(518 \times 10^{3} / \mu \mathrm{L}\right)$ were also present. Following an ECG suspicious for acute myocardial infarction (Figure 1) with ST segment elevations in precordial leads $\mathrm{V} 2$ to $\mathrm{V} 4$ and mild $\mathrm{T}$ wave inversions in the anterolateral leads, the patient received intravenous nitroglycerin and

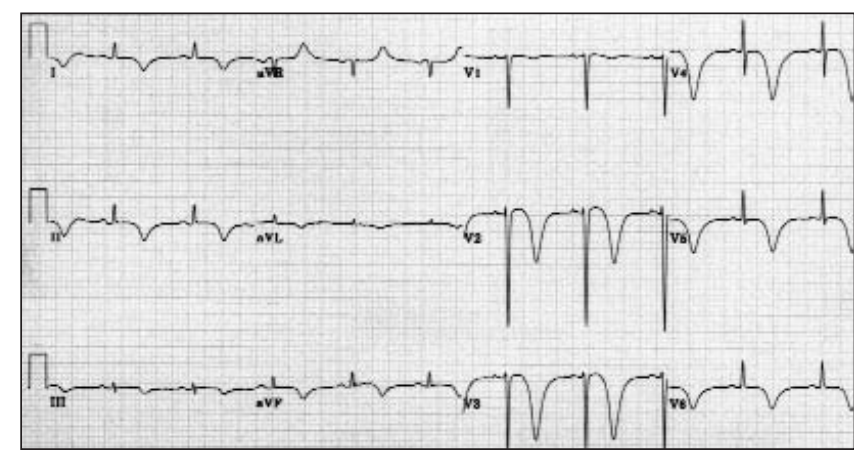

Figure 2) Electrocardiogram $28 \mathrm{~h}$ after the initial study demonstrating deeply inverted symmetric $T$ waves in all derivations

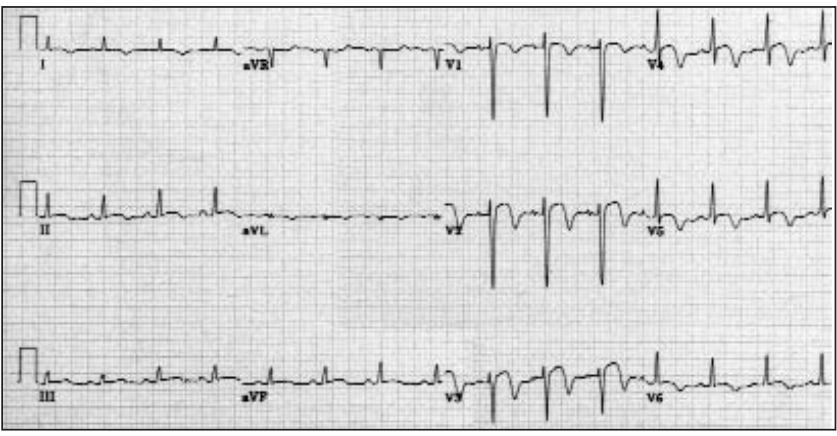

Figure 3) Electrocardiogram on the day of hospital discharge (day 8) showing persistent ST segment elevations in the anterior leads and diffuse inverted $T$ waves of lesser magnitude

was subsequently transferred to l'Hôpital du Sacré-Coeur de Montréal (Montréal, Québec) institution.

On arrival at the intensive care unit, the patient remained largely asymptomatic, with the occasional recurrence of mild epigastric discomfort. Subsequent analysis revealed peak amylase and lipase levels of $1454 \mathrm{IU} / \mathrm{L}$ and $5750 \mathrm{IU} / \mathrm{L}$, respectively. A peak creatine kinase level of $250 \mathrm{IU} / \mathrm{L}$ was seen $22 \mathrm{~h}$ after the onset of pain with an $\mathrm{MB}$ fraction of $5.0 \%$, indicating borderline significance, but this ratio was unchanged from baseline (ie, 4.7\%). Serial ECGs demonstrated the evolution of diffuse deep $\mathrm{T}$ wave inversions with persistent 1 to $2 \mathrm{~mm}$ ST segment elevations in V2 and V3 (Figure 2). No segmental wall motion abnormality, pericardial effusion, valvulopathy or diastolic dysfunction was seen on transthoracic echocardiography. The left ventricular ejection fraction was estimated at $60 \%$, and mild concentric left ventricular hypertrophy was noted. No coronary artery lesions were visualized on angiography.

An abdominal computed tomography scan revealed a small focus of inflammation surrounding the pancreatic tail, with pericaudal fat infiltration and mild thickening of Gerota's fascia. There was an unsuccessful attempt at cannulating the common bile duct by endoscopic retrograde cholangiopancreatography. The patient was discharged on day 8 with the diagnosis of acute pancreatitis of uncertain etiology with persisting anterior ST segment elevations and diffuse, but less pronounced, T wave inversions (Figure 3). 
TABLE 1

Case reports of pancreatitis associated with electrocardiographic changes simulating acute myocardial infarction

\begin{tabular}{|c|c|c|c|}
\hline Author (reference) & Year & Echocardiographic changes & Cardiac investigations \\
\hline Bauerlein and Stobbe (25) & 1954 & $\begin{array}{l}\text { Diffuse ST segment elevation most pronounced } \\
\text { in anterior leads ( } 5 \mathrm{~mm} \text { in V3) }\end{array}$ & No coronary angiography or echocardiography \\
\hline Shamma'a and Rubeiz (36) & 1962 & $\begin{array}{l}\text { Rapid atrial fibrillation with a ventricular rate of } \\
\text { 170/min; } 1 \mathrm{~mm} \text { ST segment elevations in inferior } \\
\text { leads with subsequent pathological Q waves }\end{array}$ & $\begin{array}{l}\text { No coronary angiography or echocardiography; } \\
\text { myocardial necrosis likely }\end{array}$ \\
\hline Fulton and Marriot (26) & 1963 & $\begin{array}{l}\text { 2-3 mm ST segment elevations in leads V2-V4 } \\
\text { (while on vasopressors) }\end{array}$ & $\begin{array}{l}\text { No echocardiography or coronary angiography; } \\
\text { confirmed coronary artery atherosclerosis on autopsy }\end{array}$ \\
\hline Spritzer et al (6) & 1969 & $1.5 \mathrm{~mm}$ ST segment elevations in inferior leads & $\begin{array}{l}\text { No echocardiography; high likelihood of alcoholic } \\
\text { cardiomyopathy }\end{array}$ \\
\hline Cohen et al (5) & 1971 & 1.5-2 mm ST segment elevations in leads V2-V4 & $\begin{array}{l}\text { No echocardiography; high likelihood of alcoholic } \\
\text { cardiomyopathy }\end{array}$ \\
\hline Patel et al (2) & 1994 & 1.5-2 mm ST segment elevations in leads V3-V6 & $\begin{array}{l}\text { Segmental wall motion abnormalities and reduced } \\
\text { left ventricular function on echocardiography }\end{array}$ \\
\hline Cafri et al (1) & 1995 & 1-2 mm ST segment elevations in inferior leads & $\begin{array}{l}\text { Normal echocardiography; coronary angiography } \\
\text { not performed }\end{array}$ \\
\hline
\end{tabular}

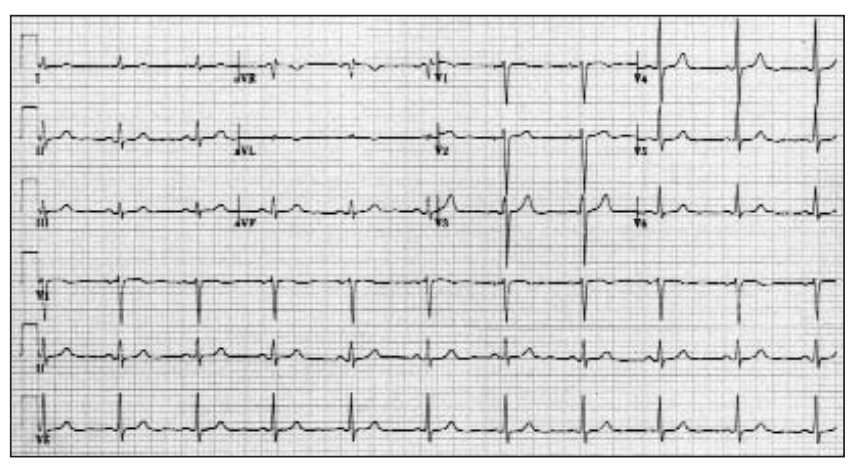

Figure 4) Baseline electrocardiogram demonstrating absence of repolarization abnormalities before the onset of pancreatitis

\section{DISCUSSION}

In 1934, Drummond (9) described the first case of acute pancreatitis associated with ECG changes compatible with myocardial ischemia. Subsequently, numerous reports and case series have documented nonspecific ST and T wave alterations associated with acute pancreatitis (3-5,7,8,10-19). Based on such observations, it is generally believed that pancreatitis, like several other inflammatory conditions such as bacterial shock (20), myocarditis (21), cholecystitis (22-24) or pneumonitis (24), may produce minor transient ECG changes most frequently involving $T$ wave inversions or ST segment depression.

Whether pancreatitis may induce major ECG changes in the absence of cardiac pathology remains a subject of controversy $(1,2,5,6,25,26)$. Rarely, ECG changes similar to myocardial infarction occur in patients with severe pancreatitis that progresses to hemodynamic collapse $(1,10,11,20,25-35)$. The few previously reported cases of ECG changes suggestive of myocardial infarction in hemodynamically stable acute pancreatitis (Table 1) either lacked extensive cardiac investigations (ie, baseline ECG, echocardiography and coronary angiography) $(1,5,6,25,36)$ or occurred in patients with underlying cardiac pathology
$(2,26)$. Our case is, therefore, unique in several regards: mild pancreatitis simulating an anterior myocardial infarction with a prior normal ECG (Figure 4); normal echocardiographic and angiographic studies; and markedly pathological $\mathrm{T}$ wave inversions.

Several hypotheses may be proposed to explain the ECG changes in acute pancreatitis. Pancreatitis is often accompanied by such metabolic abnormalities as hypocalcemia, hyponatremia, hypokalemia, hypomagnesemia and insulininduced hypoglycemia $(37,38)$. Although such electrolyte disturbances may affect myocardial repolarization, no change in our patient's baseline electrolytes was noted. Furthermore, ST segment elevation would not be an expected finding with electrolyte disturbances, which more characteristically produce QT prolongation, ST segment depression, $U$ waves and low amplitude $T$ wave changes (4).

Pancreatic proteolytic enzymes such as trypsin 1 may have resulted in direct injury to the pericardium or myocyte membrane, leading to changes in cell permeability with possible necrosis and consequent electrical changes. Kellner and Robertson (39) demonstrated ECG changes after the intravenous injection of proteolytic enzymes that took two weeks to resolve. Several authors have speculated that such damage may lead to a transient local hyperkalemia sufficient to block depolarization, which is not corrected by normalizing the electrolytes (5). Others argue that electrical changes induced by proteolytic enzymes, lipases or phospholipolytic enzymes are not secondary to myocardial necrosis, but rather to sublethal damage (40) because ECG changes should be transient (41) and no histological evidence has demonstrated myonecrosis (19). Bradykinins are also increased in acute pancreatitis but have no known relationship to ECG abnormalities $(24,42)$. In our patient, the initial concave upward ST segment elevations in leads V2 and V3 (Figure 1) may have suggested acute pericarditis. However, ST segment elevations in acute pericarditis are characteristically either diffuse or in 'epicardial' lateral leads (43), and $\mathrm{T}$ wave inversions are rarely 
seen before ST segments return to baseline (44). Furthermore, no pleuritic chest pain, pericardial friction rub or pericardial effusion was present in our patient.

Several investigators have postulated the existence of a cardiobiliary reflex $(22,23,45-47)$, which may cause cardiac damage by direct action on the myocardium or by altering coronary blood flow $(48,49)$. Although innervation to the heart and gallbladder arises from different spinal levels, Morrison and Swulim (49) evoked the possibility of a vagally mediated reflex, later shown to travel through intermediate neurons connecting these rami. This reflex has been cited as the presumed cause of $T$ wave changes in acute cholecystitis and has also been suspected in pancreatitis, gastrointestinal hemorrhage and intracranial bleeds (22). Gilbert et al (50) demonstrated reduced coronary blood flow after abdominal stimulation, which they hypothesized to be secondary to the cardobiliary reflex. In a study of prolonged vagal stimulation in animals, Manning et al (48) reported $\mathrm{T}$ wave inversions and myocardial damage. Furthermore, the cardiobiliary reflex has been inhibited experimentally by atropine and vagotomy (51). Some studies, however, have reported vagally mediated ECG changes only in subjects with underlying coronary artery disease. Hodge et al (45) noted ECG changes with gallbladder distention in dogs only when experimentally induced coronary

\section{REFERENCES}

1. Cafri C, Basok A, Katz A, et al. Thrombolytic therapy in acute pancreatitis presenting as acute myocardial infarction. Int J Cardiol 1995;49:279-81.

2. Patel J, Movahed A, Reeves WC. Electrocardiographic and segmental wall motion abnormalities in pancreatitis mimicking myocardial infarction. Clin Cardiol 1994;17:505-9.

3. Mautner RK, Siegel LA, Giles TD, et al. Electrocardiographic changes in acute pancreatitis. South Med J 1982;75:317-20.

4. Buch J, Buch A, Schmidt A. Transient ECG changes during acute attacks of pancreatitis. Acta Cardiol 1980;35:381-90.

5. Cohen MH, Rotsztain A, Bowen PJ, et al. Electrocardiographic changes in acute pancreatitis resembling acute myocardial infarction. Am Heart J 1971;82:672-7.

6. Spritzer HW, Peterson CR, Jones RC, et al. Electrocardiographic abnormalities in acute pancreatitis: two patients studied by selective coronary arteriography. Mil Med 1969;134:687-93.

7. Tuzhilin DA, Dreiling DA. Cardiovascular lesions in pancreatitis. Am J Gastroenterol 1975;63:381-8.

8. Lévy A, Kieffer L, Frank P. Troubles de la repolarisation ventriculaire gauche au cours d'une pancréatite aiguë cytostéatonécrotique. Evolution électrocardiographique sous l'effet des antiferments. Sem Hop 1998;45:655-7.

9. Drummond J. Cardiac abnormalities of abdominal origin. S Afr Med J 1934;8:520-6.

10. Dittler TL, McGavack TH. Pancreatic necrosis associated with auricular fibrillation and flutter; report of case simulating coronary thrombosis (autopsy finding). Am Heart J 1938;16:354-7.

11. Gottesman J, Casten D, Beller AJ. Changes in the electrocardiogram induced by acute pancreatitis; clinical and experimental study. JAMA 1943;123:892-4.

12. Eskwith I, Cacace VA, Sollosy A. Acute hemorrhagic pancreatitis. N Engl J Med 1955;252:494-5.

13. Leger L, Périer R, Lesur A. Syndromes abdominaux et électrocardiogramme. Presse Méd 1955;63:1744-8.

14. Pollock AV. Acute pancreatitis, analysis of 100 patients. BMJ 1959;i:6-14.

15. Lambert H. Electrocardiographic changes in acute pancreatitis. Cardiology 1966;48:387-90.

16. Godeau P, Derrida JP, Herreman G, et al. Cardiovascular manifestations of pancreatitis. Apropos of 4 cases. Sem Hop 1975;51:2383-92. lesions were produced. A later study of 26 patients undergoing biliary tract surgery in whom the gallbladder and common bile duct were distended confirmed ECG changes only in the presence of underlying coronary artery disease (47). Furthermore, ST segment elevations secondary to the cardiobiliary reflex have not been previously documented.

Other possible mechanisms such as coronary vasospasm (20), exacerbation of underlying coronary artery disease (22), or coronary thrombus formation secondary to increased platelet adhesiveness or pancreatic enzymeinduced coagulopathy (41) are unlikely in our patient given the prolonged duration of ST segment elevation and the normal coronary angiogram.

In the era of thrombolysis, misdiagnosing acute myocardial infarction in the presence of abdominal pathology may lead to serious hemorrhagic complications. Our case report demonstrates that despite the absence of hemodynamic instability, underlying cardiac disease or the use of vasopressors, acute pancreatitis may mimic the ECG changes seen with myocardial infarction. In selected cases, complementary noninvasive and invasive studies may be required to establish a definitive diagnosis. Further studies are required to determine whether, in the absence of hemodynamic instability, ECG abnormalities seen in pancreatitis have etiological, prognostic or therapeutic implications.

17. Denizeau JP, Touaty E, Baligadoo S. Complete atrioventricular block and acute pancreatitis. Coeur Med Interne 1976;15:487-9.

18. Bartolome E, Garnacho A, Frison JC, et al. Electrocardiographic changes in acute pancreatitis. Rev Esp Enferm Apar Dig 1977;49:539-44.

19. Pollock AV, Bertrand DA. Electrocardiographic changes in acute pancreatitis. Surgery 1956;40:951-6.

20. Terradellas JB, Bellot JF, Saris AB, et al. Acute and transient ST segment elevation during bacterial shock in seven patients without apparent heart disease. Chest 1982;81:444-8.

21. Waldman HM, Palacios IF, Hutter AM, et al. Biopsy proven myocarditis mimicking acute myocardial infarction. Circulation 1988;78(Suppl 2):457. (Abst)

22. Krasna MJ, Flancbaum L. Electrocardiographic changes in cardiac patients with acute gallbladder disease. Am Surg 1986;52:541-3.

23. Dickerman JL. Electrocardiographic changes in acute cholecystitis. J Am Osteopath Assoc 1989;89:630-5.

24. Ryan ET, Pak PH, DeSanctis RW. Myocardial infarction mimicked by acute cholecystitis. Ann Intern Med 1992;116:218-20.

25. Bauerlein TC, Stobbe LHO. Acute pancreatitis simulating myocardial infarction with characteristic electrocardiographic changes. Gastroenterology 1954;27:861-4.

26. Fulton MC, Marriot HJ. Acute pancreatitis simulating myocardial infarction in the electrocardiogram. Ann Intern Med 1963;59:730-2.

27. Cunnion RE, Parrillo JE. Myocardial dysfunction in sepsis. Recent insights. Chest 1989;95:941-5.

28. Parker MM, Shelhamer JH, Bacharach SL, et al. Profound but reversible myocardial depression in patients with septic shock. Ann Intern Med 1984;100:483-90.

29. Parker MM, McCarthy KE, Ognibene FP, et al. Right ventricular dysfunction and dilatation, similar to left ventricular changes, characterize the cardiac depression of septic shock in humans. Chest 1990;97:126-31.

30. Ellrodt AG, Riedinger MS, Kimchi A, et al. Left ventricular performance in septic shock: reversible segmental and global abnormalities. Am Heart J 1985;110:402-9.

31. Hess ML, Soulsby ME, Davis JA, et al. The influence of venous return on cardiac mechanical and sarcoplasmic reticulum function during endotoxemia. Circ Shock 1977;4:143-52.

32. Clowes GHJ, Martin H, Walji S, et al. Blood insulin responses to blood glucose levels in high output sepsis and septic shock. Am J Surg 1978;135:577-83. 
33. Nayler WG, McInnes I, Stone J, et al. Effect of dopamine on coronary vascular resistance and myocardial function. Cardiovasc Res 1971;5:161-8.

34. Vatner SF, Millard RW, Higgins CB. Coronary and myocardial effects of dopamine in the conscious dog: parasympatholytic augmentation of pressor and inotropic actions. J Pharmacol Exp Ther $1973 ; 187: 280-95$

35. Brooks HL, Stein PD, Matson JL, et al. Dopamine-induced alterations in coronary hemodynamics in dogs. Circ Res 1969;24:699-704.

36. Shamma'a MH, Rubeiz GH. Acute pancreatitis with electrocardiographic findings of myocardial infarction. Am J Med 1962;32:827-30.

37. Leak D, Starr P. The mechanism of arrhythmias during insulin induced hypoglycemia. Am Heart J 1962;63:688-91.

38. Read RC, Doherty JE. Cardiovascular effects of induced insulin hypoglycemia in man during the Hollander test. Am J Surg 1970;119:155-62.

39. Kellner A, Robertson T. Selective necrosis of cardiac and skeletal muscle induced experimentally by means of proteolytic enzyme solutions given intravenously. J Exp Med 1954;99:387-403.

40. Webster PD, Zieve L. Alterations in serum content of pancreatic enzymes. N Engl J Med 1962;267:554-8.

41. Lieberman JS, Taylor A, Wright IS. The effect of intravenous trypsin administration on the electrocardiogram in the rabbit. Circulation $1954 ; 10: 338-42$.
42. Katz W, Silverstein M, Kobold EE, et al. Trypsin release, kinin production, and shock: relationship in experimental and human pancreatitis. Arch Surg 1965;91:14-20.

43. Kouvaras G, Soufras G, Chronopoulos G, et al. The ST segment axis as a differential diagnostic feature between acute pericarditis and acute inferior myocardial infarction. Angiology 1990;41:207-12.

44. Bruce MA, Spodick DH. Atypical electrocardiogram in acute pericarditis: characteristics and prevalence. J Electrocardiol 1980;13:61-6.

45. Hodge GB, Messer AL, Hill H. Effect of distention of the biliary tract on the electrocardiogram. Arch Surg 1947;55:710-22.

46. Hampton AG, Beckwith JR, Wood JE. The relationship between heart disease and gallbladder disease. Ann Intern Med 1957;50:1135-45.

47. Hodge GB, Messer AL. The electrocardiogram in biliary tract disease and during experimental biliary distention: clinical observations on 26 patients. Surg Gynecol Obstet 1948;86:617-26.

48. Manning GW, Hall GE, Barting FG. Vagus stimulation and the production of myocardial damage. CMAJ 1937;37:314-8.

49. Morrison LM, Swulim WA. Role of the gastrointestinal tract in production of cardiac symptoms. JAMA 1940;114:217-23.

50. Gilbert NC, Fern GK, LeRoy GV. The effect of distention of abdominal viscera on coronary blood flow. Am Heart J 1940;20:519-24.

51. Kaufman JM, Lubera R. Preoperative use of atropine and electrocardiographic changes. Differentiation of ischemic from biliaryinduced abnormalities. JAMA 1967;200:197-200. 


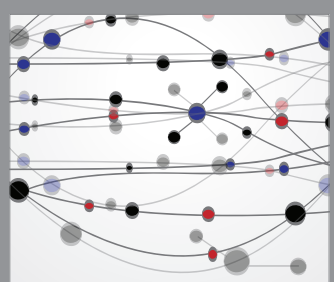

The Scientific World Journal
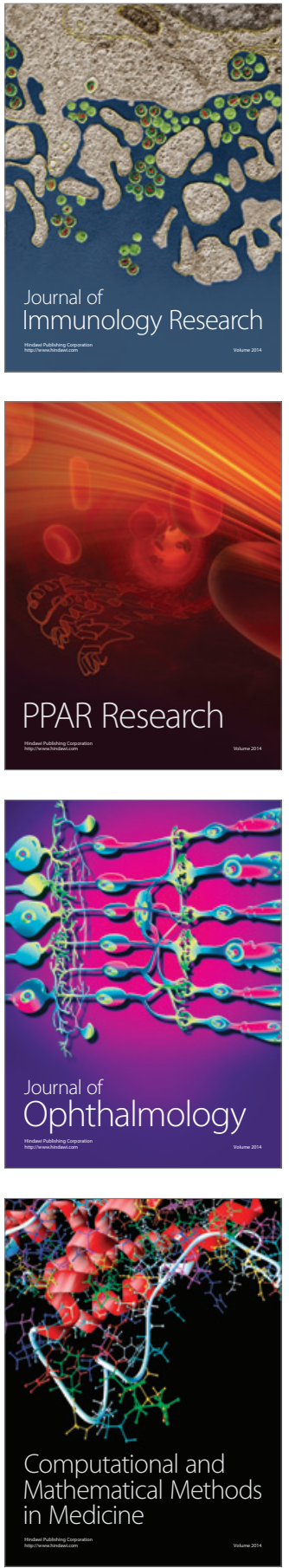

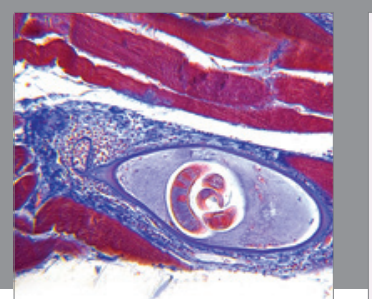

Gastroenterology Research and Practice

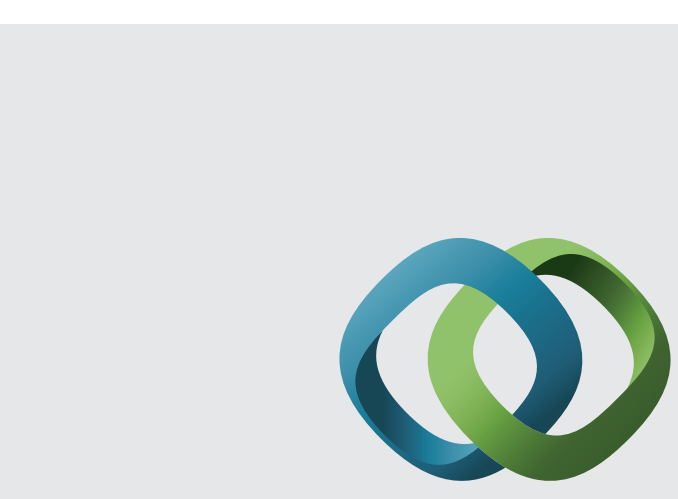

\section{Hindawi}

Submit your manuscripts at

http://www.hindawi.com
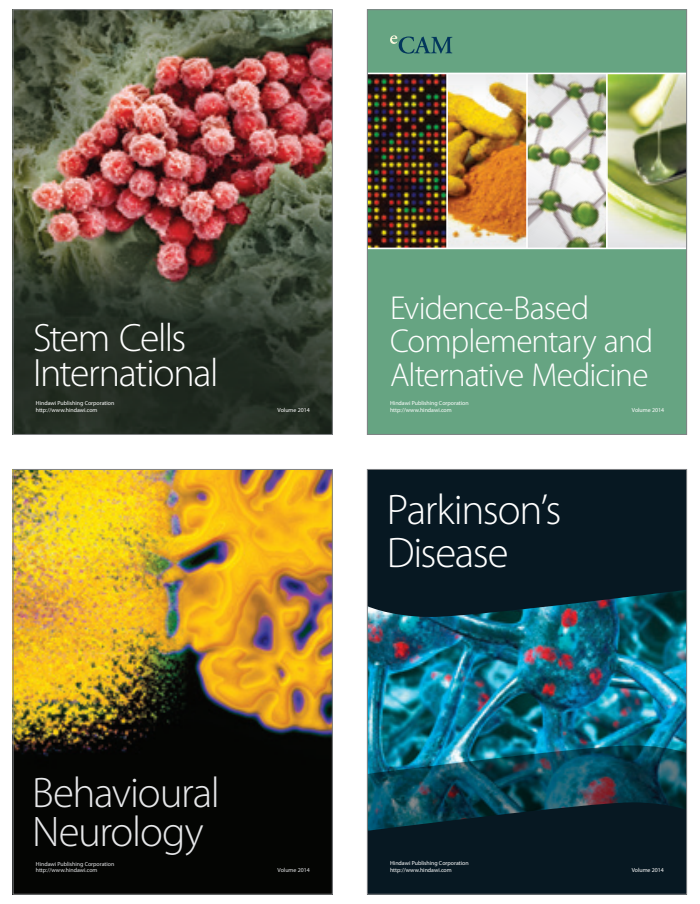
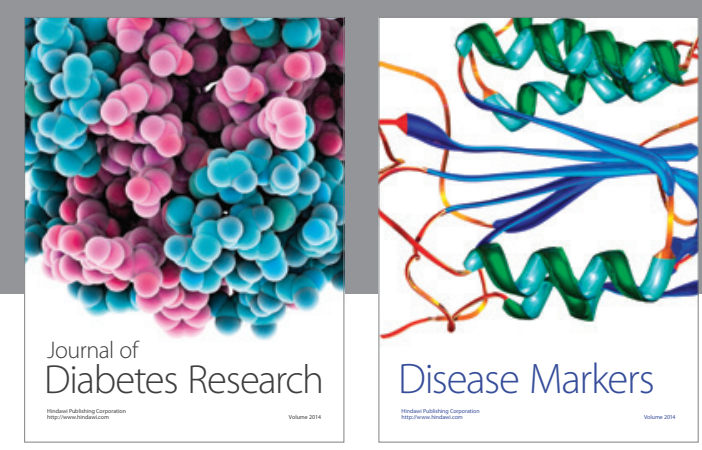

Disease Markers
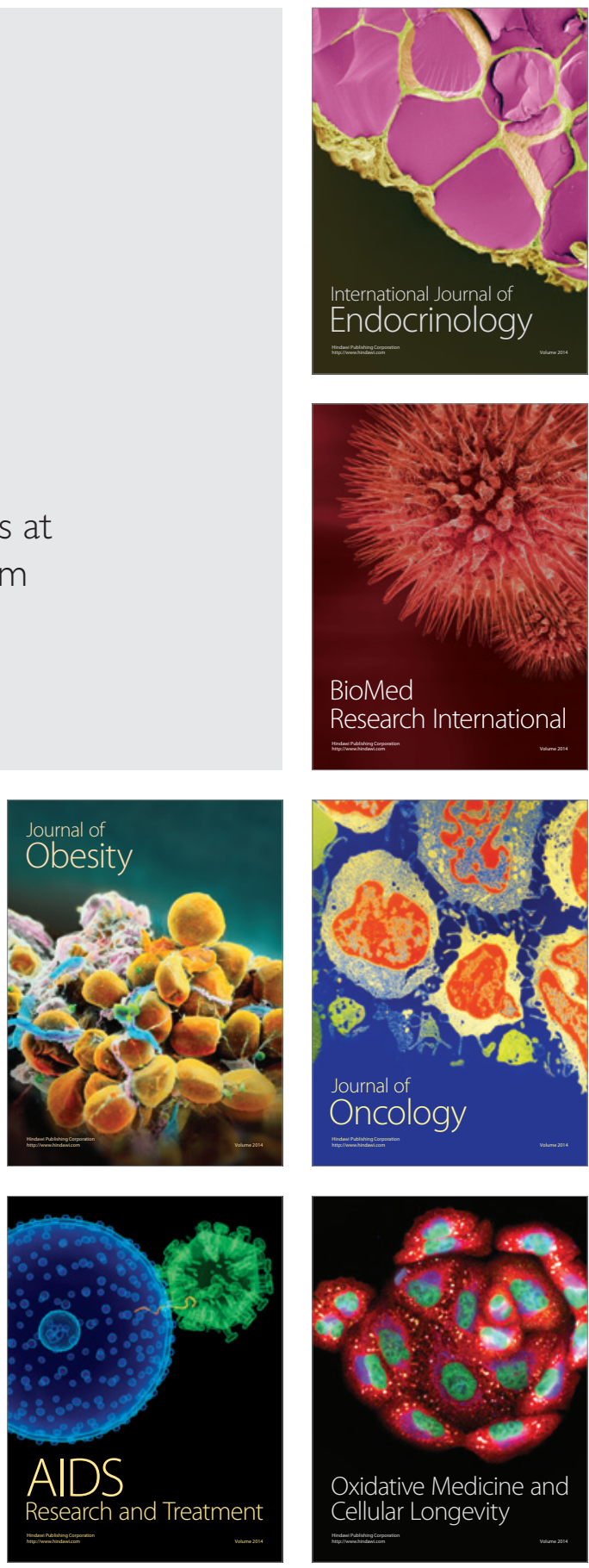